\title{
Kepemimpinan transformasional dalam meningkatkan motivasi intrinsic dan kinerja pegawai; analisis mediasi model
}

\author{
Desi Natalia \\ Fakultas Ekokonomi dan Bisnis, Universitas Palangka Raya
}

\begin{abstract}
Abstrak
Tujuan, - Penelitian ini bertujuan untuk menguji dan menganalisis lebih besar mana pengaruh dari peran kepemimpinan transformational terhadap motivasi intrinsik dan kinerja pegawai.

Desain/Methodologi/Pendekatan - Dengan menggunakan 54 Pegawai Negeri Sipil di Bappedalitbang Provinsi Kalimantan Tengah. Pengujian Analisis data menggunakan SmartPLS untuk menguji pengaruh langsung maupun pengaruh tidak langsung,

Temuan penelitian - Hasil penelitian menunjukkan bahwa motivasi intrinsic memediasi hubungan antara kepimpinan transformasional dan kinerja pegawai. Jenis mediasi dalam penelitian ini adalah komplementari mediasi parsial. Sedangkan pengaruh langsung antara kepemimpinan transformasional dan motivasi intrinsic terhadap kinerja terbukti berpengaruh positif signifikan.

Orisinalitas/nilai - Nilai tambah dari hasil penelitian ini berkontribusi untuk menjelaskan lebih dominan mana pengaruh kepemimpinan transformasional dalam meningkatkan pegaruh langsung terhada motivasi intrinsk dan kinerja pegawai
\end{abstract}

Kata kunci: Kepemimpinan transformasional, kinerja pegawai, motivasi intrinsik Jenis artikel: Artikel penelitian

\section{Transformational leadership in increasing intrinsic motivation and employee performance; mediation model analysis}

\begin{abstract}
Objectives, - This study aims to examine and analyze the greater the influence of the transformational leadership role on intrinsic motivation and employee performance.

Design/Methodology/Approach - Using 54 Civil Servants in Central Kalimantan Province. Testing Data analysis using SmartPLS to test the direct and indirect effects,

Research Findings - The results show that intrinsic motivation mediates the relationship between transformational leadership and employee performance. The type of mediation in this study is complementary partial mediation. Meanwhile, the direct influence between transformational leadership and intrinsic motivation on performance has been shown to have a significant positive effect.

Originality/value - The added value of the results of this study contributes to explaining which is the dominant influence of transformational leadership in increasing the direct influence on intrinsic motivation and employee performance.
\end{abstract}

Keywords: transformational leadership, Employee performance, intrinsic motivation Paper type: Research Paper 


\section{Pendahuluan}

Salah satu pendekatan kepemimpinan saat ini dan paling populer yang telah menjadi fokus banyak penelitian sejak awal 1980-an adalah pendekatan transformasional. Kepemimpinan transformasional merupakan bagian dari paradigma "Kepemimpinan Baru" (Bryman, 1992), yang lebih memperhatikan unsur karismatik dan afektif kepemimpinan. Kepemimpinan menjadi salah satu faktor kunci dalam suksesnya suatu organisasi serta manajemen termasuk didalamnya adalah organisasi sektor publik. Kepemimpinan yang efektif di sektor publik dibentuk tidak hanya oleh sifat-sifat pribadi dan karakteristik seorang pemimpin, tetapi juga oleh gaya para pemimpin menghadapi situasi dengan perilaku pemimpin yang tepat disertai dengan beberapa praktek pengembangan kepemimpinan seperti pendidikan dan pelatihan (Sambung, 2020). Keberhasilan seorang pemimpin dalam menggerakan orang lain atau pengikutnya dalam mencapai tujuan yang telah ditetapkan sangat tergantung kepada kewibawaan, dan juga pemimpin itu dalam menciptakan motivasi di dalam diri setiap bawahan, kolega, maupun atasan pemimpin itu sendiri. Gaya kepemimpinan transformasional telah diterima secara luas dan lebih populer dibandingkan dengan gaya kepemimpinan lain di antara para peneliti kepemimpinan (Carter et al., 2014; Suifan et al., 2018; Zhang et al., 2020).

Kepemimpinan transformasional merupakan salah satu dimensi penting dalam kepemimpinan efektif yang sekaligus menjadi prediktor terkuat atas hasil kepemimpinan (leadership outcomes), seperti usaha ekstra para bawahan terhadap ketrampilan kepemimpinan (Seltzer \& Bass, 1990). Model kepemimpinan yang ditampilkan seorang pemimpin transformasional diharapkan dapat meningkatkan motivasi dan kinerja bawahan untuk mencapai hasil kerja yang optimal. Model kepemimpinan ini merupakan salah satu model kepemimpinan yang mulai diperhitungkan kegunaannya dalam menghadapi perubahan organisasi. Burns dalam Northouse (2016) menyatakan kepemimpinan transformasional merupakan proses dimana orang terlibat dengan orang lain, dan menciptakan hubungan yang meningkatkan motivasi dan moralitas dalam diri pemimpin dan pengikut.

Istilah kepemimpinan transformasional pertamakali diciptakan oleh Downton (1973), hal ini muncul sebagai pendekatan yang penting untuk kepemimpinan. Di dalam karyanya, Burns berupaya untuk menghubungkan peran kepemimpinan dan pengikut. Dia menulis tentang pemimpin sebagai orang yang meningkatkan motif pengikut, untuk bisa mencapai tujuan pemimpin dan pengikut secara lebih baik. Orang yang menampilkan kepemimpinan transformasional sering kali memiliki kumpulan nilai serta prinsip internal yang kuat. Mereka efektif dalam memotivasi pengikut untuk bertindak dalam cara yang mendukung kepentingan yang lebih besar, dari pada kepentingan mereka sendiri (Northouse 2016).

Pengaruh Ideal, Stimulasi Intelektual, dan Motivasi Inspirasional yang merupakan dimensi dari kepemimpinan transformasional memiliki pengaruh yang besar pada inovasi organisasi dan kreativitas pegawai, dan motivasi intrinsik mampu memoderasi secara positif hubungan antara kepemimpinan transformasional dan kreativitas pegawai. Dengan demikian, melalui gaya kepemimpinan transformasional, menginspirasi karyawan untuk berpikir secara kreatif dan mengarah pada inovasi dalam organisasi (Shafi et al., 2020). Pemimpin transformasional yang bersifat sosial ini mengalahkan kepentingan mereka sendiri demi kebaikan orang lain (Howell \& Avolio, 1993). Gaya kepemimpinan transformasional merupakan salah satu kepemimpinan yang mampu meningkatkan kinerja pegawai (Lai et al., 2020; Yammarino et al., 1993), bahkan tidak hanya kinerja pegawai saja juga mampu meningkatkan kreativitas pegawai dalam bekerja (Jyoti \& Dev, 2015; Sambung, 2020; Shafi et al., 2020). Kinerja merupakan salah satu fungsi yang sangat berpengaruh dalam pencapaian tujuan organisasi disamping fungsi dan faktor-faktor lainnya. Kinerja pegawai yang tinggi sangatlah diharapkan oleh Organisasi tersebut. Semakin banyak pegawai yang mempunyai kinerja yang baik, maka 
semakin bagus pula produktivitas yang dihasilkan oleh organisasi.

Selain berpengaruh terhadap kinerja, penelitian yang menjelaskan hubungan antara kepemimpinan transformasional dan motivasi. Terdapat hubungan yang erat antar kepemimpinan transformasional terhadap motivasi kerja (Masi \& Cooke, 2000; Nugroho et al., 2020).

Berdasarkan penelitian yang dijelaskan diatas maka dapat disimpulkan bahwa penelitian ini mencoba menyederhanakan model penelitian, dengan berupaya untuk menjelaskan bahwa konsep teori dari kepemimpinan berpengaruh kuat terhadap kinerja pekerjaan pegawai secara langsung ataukah berpengaruh kuat terhadap peningkatan motivasi intrinsik pegawai. Usulan penelitian ini akan berdampak pada penambahan penjelasan dari teori kepemimpinan.

\section{Teori dan pengembangan kerangka konseptual}

\section{Kepemimpinan transformasional (KT)}

Setelah James McGregor Burns memperkenalkan konsep pemimpin yang mentransformasi, ide-idenya terus berdampak besar pada cara kita memikirkan dan menerapkan teori kepemimpinan. Secara sederhana, tesis Burns (1978) adalah bahwa para pemimpin besar adalah transformasional dalam arti bahwa mereka "berfungsi sebagai kekuatan independen dalam mengubah susunan basis motif pengikut ..." (Burns, 1978). Pada era berikutnya, para peneliti kepemimpinan berusaha untuk memperbaiki, memperluas, dan secara empiris memvalidasi teori kepemimpinan transformasional menjadi apa yang telah menjadi paradigma kepemimpinan yang paling banyak diteliti (Northouse, 2016). KT adalah proses dimana seseorang terlibat dengan orang lain dan menciptakan hubungan yang meningkatkan tingkat motivasi dan moralitas baik dalam pemimpin dan pengikut. Tipe pemimpin ini memperhatikan kebutuhan dan motif pengikut dan mencoba membantu pengikut mencapai potensi penuh mereka (Northouse, 2019).

\section{Motivasi intrinsik (MI)}

Isitlah motivasi (motivation) berasal dari bahasa Latin, yaitu "movere" yang artinya "menggerakkan" (to move). Gray dalam (Hamali, 2016) mendefinisi motivasi sebagai hasil sejumlah proses yang bersifat internal atau eksternal bagi seorang individu, yang menyebabkan timbulnya antusiasme dan persistence dalam melakasanakan kegiatan-kegiatan tertentu. Motivasi intrinsik adalah pendorong kerja yang bersumber dari dalam diri. MI adalah minat karyawan untuk melakukan tugas tertentu untuk kepentingan mereka sendiri alih-alih pengaruh eksternal (Gumusluoglu \& Ilsev, 2009).

\section{Kinerja pekerjaan (KP)}

Kinerja pekerjaan adalah manfaat organisasi penting yang berasal dari kepemimpinan transformasional. Babin \& Boles, (1998) mendefinisikan konstruksi ini sebagai "tingkat produktivitas individu karyawan, dibandingkan terhadap rekan-rekannya, pada beberapa perilaku dan hasil yang berhubungan dengan pekerjaan.

\section{Hipotesis}

\section{Kepemimpinan transformasional dan kinerja}

Kepemimpin transformasional dapat meningkatkan kinerja pengikut atau kinerja pekerjaan anggota organisasi (Lai et al., 2020). Dimensi dari kepemimpinan transformasional memiliki pengaruh yang besar terhadap kinerja, termasuk mendorong menikatnya inovasi organisasi dan krativitas pegawai, (Shafi et al., 2020). Disimpulkan bahwa secara hubungan konseptual ada hubungan antara KT dan KP, maka hipotesis penelitian adalah: 
Hipotesis 1 : Kepemimpinan transformasional berpengaruh positif terhadap kinerja pekerjaan pegawai

\section{Kepemimpinan transformasional dan motivasi intrinsik}

Penelitian yang menjelaskan hubungan antara kepemimpinan transformasional dan motivasi. Terdapat hubungan yang erat antar kepemimpinan transformasional terhadap motivasi kerja (Masi \& Cooke, 2000; Nugroho et al., 2020). Orang yang menampilkan kepemimpinan transformasional sering kali memiliki kumpulan nilai serta prinsip internal yang kuat. Mereka efektif dalam memotivasi pengikut untuk bertindak dalam cara yang mendukung kepentingan yang lebih besar, dari pada kepentingan mereka sendiri (Northouse 2016). Disimpulkan bahwa ada hubungan antara kepemimpinan transformasional dalam meningkatkan motivasi intriksi pegawa, maka hipotesis penelitian adalah:

Hipotesis 2 : Kepemimpinan transformasional berpengaruh positif terhadap motivasi intrinsik pegawai

Berdasarkan penjelasan secara empiris masing-masing hubungan penelitian tersebut diatas, maka gambar hubungan kerangka konseptual penelitian ini sebagai berikut:

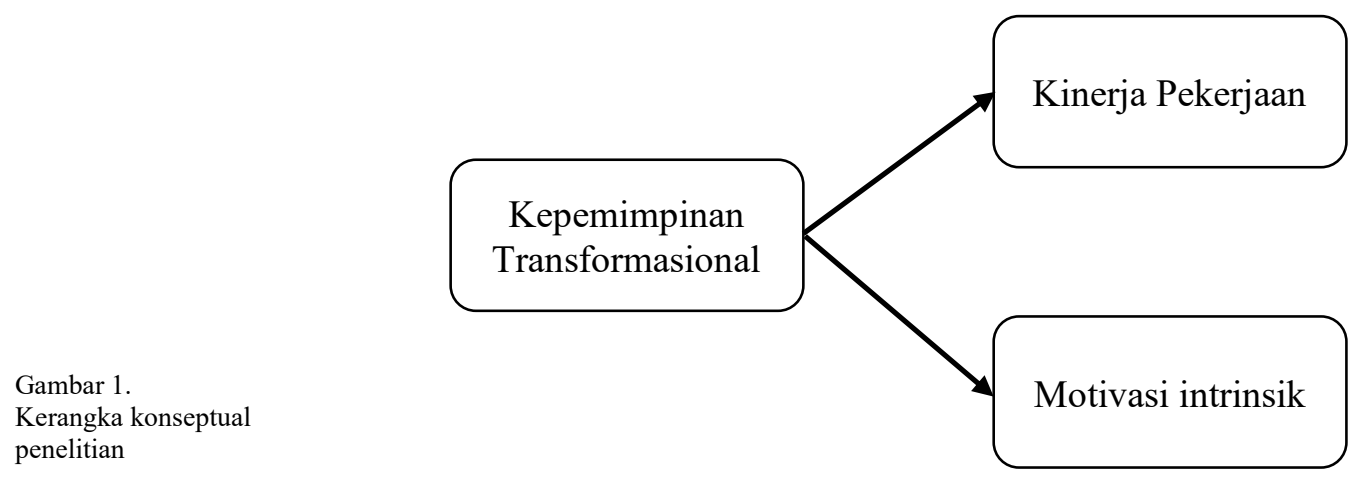

\section{Metode}

\section{Sampel dan prosedur}

Sampel dalam penelitian ini adalah pegawai negeri sipil kantor Bappedalitbang Kota Palangka Raya yang berjumlah 54 orang dengan menggunakan sampel acak sederhana. Melakukan analisi data dengan menggunakan alat analisis smart PLS. Pemilihan alat analisis tersebut dikarenakan variabel yang digunakan menggunakan indikator dalam mengukur variabel, sehingga jenis variabelnya adalah variable laten. Smart PLS 3.3.0 digunakan dalam penelitian ini karena mampu diterapkan pada setiap jenis skala data (nominal, ordinal, interval, rasio) serta syarat asumsi yang lebih fleksibel. Pendekatan PLS didasarkan pada pergeseran analisis dari pengukuran estimasi parameter model menjadi pengukuran prediksi yang relevan. Sehingga fokus analisis bergeser dari hanya estimasi dan penafsiran signifikansi parameter menjadi validitas dan akurasi prediksi. Alat analisis ini juga sangat tepat untuk penelitian yang bersifat prediksi, menguji hubungan sebab akibat. Selama melakukan analisis data kami menerapkan nilai-nilai cut-off evaluasi outer model tahap 1 yaitu, reliabilitas indikator, dengan nilai loading masing-masing indikator mulai dari dari 0,7 keatas (Wong, 2013); (Sarstedt et al., 2017) Internal Conistency Reliability, dengan melihat composite reliability dan cronbach's alpha, nilai cut off 06 -07 (Ghozali \& Latan, 2015); Alpha Cronbach lebih tinggi dari 0,6 (Ghozali \& Latan, 2015); Validitas konvergen, dievaluasi dengan Average 
Variance Extracted (AVE) sama dengan 0,5 atau lebih tinggi (Wong, 2013); (Sarstedt et al., 2017); Validitas diskriminan, evaluasi menggunakan nilai cross loading sama dengan atau lebih besar dari 0,7 dan fornell Larcker Criterion dengan membandingkan nilai akar kuadrat dari AVE terhadap terhadap setipa konsturk. Nilai akar AVE > dari Nilai korelasi lainnya. Nilai cut off yang digunakan untuk mengevaluasi inner model: Uji Kolinearitas dievaluasi dengan nilai VIF, nilai harus dibawah 5. Koefesien determinasi (R2) diharapkan 0 dan 1. Nilai R2 = 0,75 kuat; 0,50 moderat dan 0,25 lemah (Sarstedt et al., 2017). Chin memberikan kriteria nilai R2 sebesar 0,67 kuat, 0,33 moderat dan 0,19 lemah (dalam Ghozali \& Latan, 2015). Cross-validated redundancy (Q2 ) atau Q-square test menggunakan predictive relevance. Nilai $>$ dari 0 Q2 akurat terhadap konstruk (Sarstedt et al., 2017). Pengukuran path coeffecient antar konstruk untuk melihat signifikansi, nilai -1 hingga +1 . semakin mendekati +1 hubungan kedua konstruk semakin kuat (Sarstedt et al., 2017).

\section{Pengukuran}

Kepemimpinan transformasional, kuesioner kepemimpinan multifaktor (Bass \& Avolio, 1994) digunakan untuk menilai kepemimpinan transformasional. Indikator 1)Pengaruh ideal, behaviors; 2) Pengaruh ideal attributes; 3) Motivasi inspirasional; 4) Stimulasi intelektual, dan 5)Perilaku individu. Responden menilai semua item dengan skala Likert 5 poin $(1=$ sangat tidak setuju; $5=$ sangat setuju).

Motivasi intrinsik, kuesioner motivasi intrinsik dari Herzberg dalam Luthans (2011). Responden menilai semua item dengan skala Likert 5 poin $(1=$ sangat tidak setuju; $5=$ sangat setuju). Indikator motivasi intrinsik 1)Keberhasilan, 2)Pengakuan, 3)Pekerjaan itu sendiri, 4) Tanggung jawab dan 5) Pengembangan.

Kinerja pekerjaan, kuesioner kinerja pekerjaan dari Wilson dalam Setiawan, (2019). Responden menilai semua item dengan skala Likert 5 poin $(1=$ sangat tidak setuju; $5=$ sangat setuju). Indikator untuk mengukur kinerja pekerjaan, 1) Jumlah pekerjaan, 2) Kualitas pekerjaan, 3) Ketepatan waktu, 4) Kehadiran, 5) Kemampuan Kerjasama.

\begin{tabular}{llll}
\hline No & \multicolumn{1}{c}{ Variabel } & \multicolumn{1}{c}{ Indikator } \\
\hline 1. & Kepemimpinan transformasional & 1. Pengaruh ideal behaviors \\
& (KT) & 2. Pengaruh ideal attributes \\
& (Burns dalam Northouse 2013) & 3. Motivasi inspirasional \\
& & 4. Stimulasi intelektual \\
\hline 2. & Motivasi intrinsik (Y1) & 5. Perilaku individu \\
& (Herzberg dalam Luthans 2011) & 7. Peberhasilan \\
& & 8. Pekerjaan itu sendiri \\
& & 9. Tanggung jawab \\
\hline 3. & Kinerja pegawai (Y2) & 10. Pengembangan \\
& (Bangun Wilson dalam Nafi & 12. Kualitas pekerajan \\
& Setiawan, 2019) & 13. Ketepatan waktu \\
& & 14. Kehadiran \\
& & 15. Kemampuan kerjasama \\
\hline
\end{tabular}

\section{Hasil penelitian}

Berdasarkan data yang dikumpulkan dalam penelitian ini dilakukan melalui penyebaran kuesioner sebanyak 54 kuesioner kepada Pegawai Negeri Sipil pada Bappedalitbang provinsi 
Kalimantan Tengah yang digunakan untuk membuktikan hipotesis. Jumlah kuesioner yang diperoleh dari responden merupakan sesuatu yang penting untuk mengetahui karakteristik responden yang menjadi sampel dalam penelitian ini dengan informasi tentang karakteristik respondan yang dapat dilihat pada tabel 2 berikut ini :

Tabel 2. Karakteristik responden

\begin{tabular}{|c|c|c|}
\hline Kategori & Frekuensi & Persentase \\
\hline \multicolumn{3}{|c|}{ Jenis kelamin } \\
\hline Pria & 29 & $53,7 \%$ \\
\hline Wanita & 25 & $46,3 \%$ \\
\hline Total & 54 & $100 \%$ \\
\hline \multicolumn{3}{|l|}{ Usia } \\
\hline \multicolumn{3}{|c|}{ Dibawah 35 tahun } \\
\hline $35-40$ th & 17 & $31,5 \%$ \\
\hline $41-45$ th & 19 & $35,2 \%$ \\
\hline $46-50$ th & 6 & $11,1 \%$ \\
\hline$>51$ tahun & 12 & $22,2 \%$ \\
\hline Total & 54 & $100 \%$ \\
\hline \multicolumn{3}{|l|}{ Pendidikan } \\
\hline SMA & 13 & $24,1 \%$ \\
\hline Diploma & 2 & $3,7 \%$ \\
\hline S1 & 30 & $55,6 \%$ \\
\hline S2 & 9 & $16,6 \%$ \\
\hline S3 & 0 & $0 \%$ \\
\hline Total & 54 & $100 \%$ \\
\hline \multicolumn{3}{|l|}{ Pengalaman kerja } \\
\hline $10-15$ & 11 & $20,4 \%$ \\
\hline $16-20$ & 13 & $24,1 \%$ \\
\hline 21 tahun & 17 & $31,4 \%$ \\
\hline Total & 54 & $100 \%$ \\
\hline
\end{tabular}

Berdasarkan tabel 2 karakteristik responden bahwa responden dengan jenis kelamin pria lebih banya yaitu berjumlah 29 orang atau $53,7 \%$ dan yang berjenis kelamin wanita berjumlah 25 orang atau 46,3\%, dengan usia paling banyak adalah 41-45th berjumlah 19 orang atau $35,2 \%$, berusia 35-40th berjumlah 17 orang atau 31,5\%, yang berusia 46-50th berjumlah 6 orang atau $11,1 \%$, yang berusia $>51$ th berjumlah 12 orang atau $22,2 \%$. Tingkat dominan berpendidikan Sarjana berjumlah 30 orang atau 55,6\%, pendidikkan SMA berjumlah 13 orang atau 24,1\%, pendidikan Diploma berjumlah 2 orang atau 3,7\%, pendidikkan S1 pendidikkan S2 berjumlah 9 orang atau 16,6\%. Dengan masa kerja responden sebanyak 17 orang atau 31,4\% lebih dari 21 tahun.

\section{Outer Model}

Hasil model pengukuran (Outer Model) yang dilakukan menggunakan tabulasi data kuesioner dengan hasil sebagai berikut :

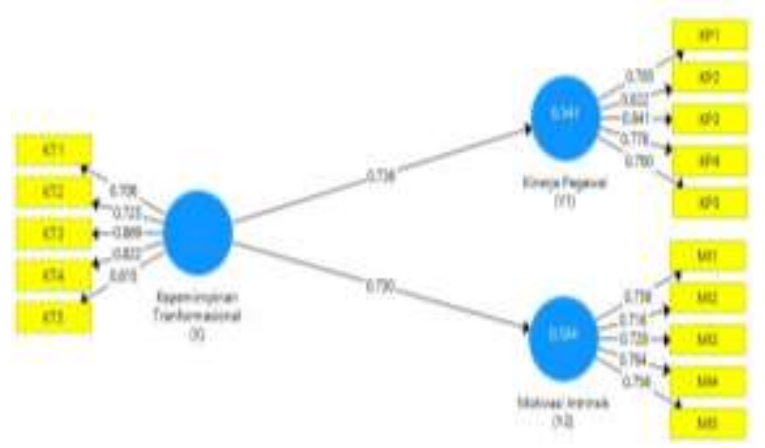


Tabel 3 Evaluasi outer loading

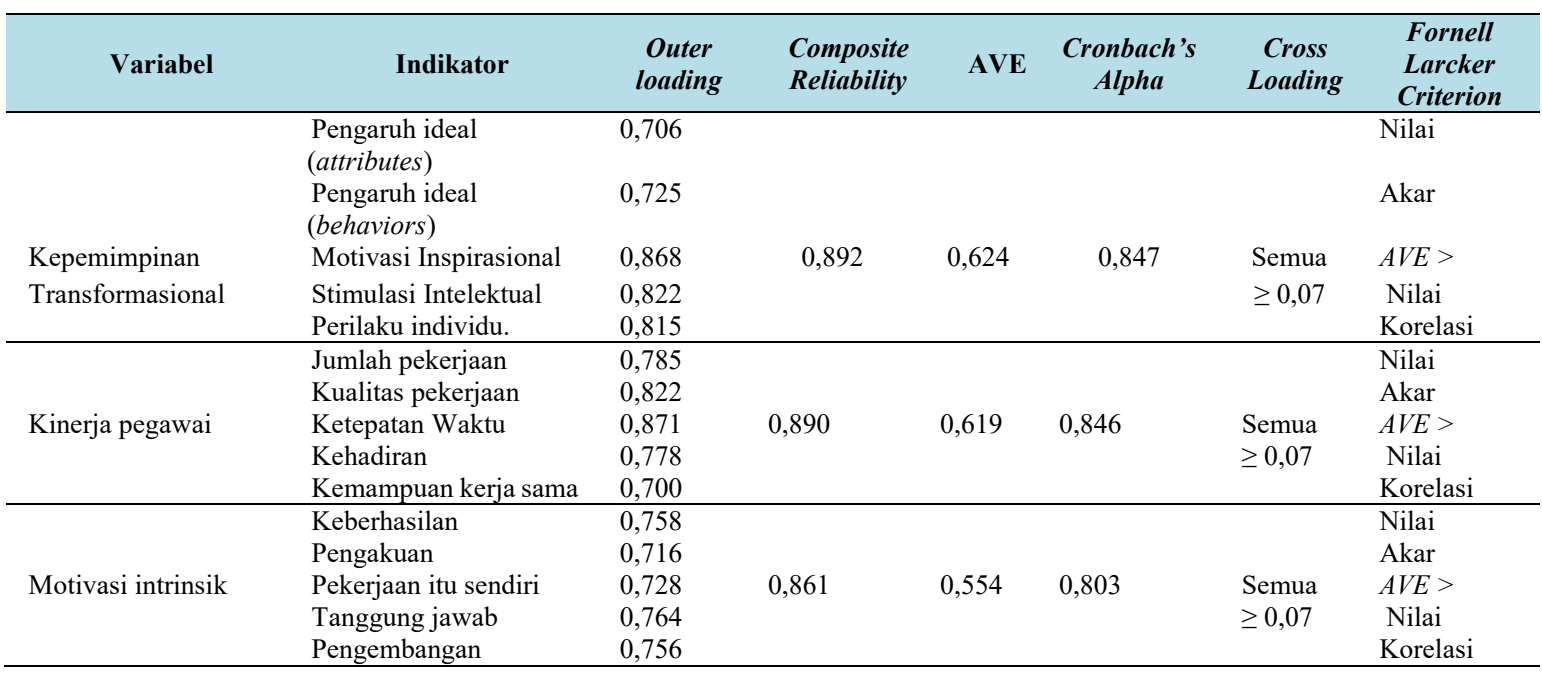

Validitas Konvergen (Convergent Validity)

Berdasarkan tabel 3 diatas, diketahui bahwa masing-masing indikator variabel penelitian memiliki outer loading yang beragam. Dari data diatas menunjukkan bahwa semua indikator memiliki nilai outer loading $>0,70$ sehingga indikator dinyatakan layak atau valid digunakan dalam penelitian dan dapat digunakan untuk analisis selanjutnya.

Dan diketahui nilai AVE (Average Variance Extracted) variabel Kepemimpinan transformasional, kinerja dan motivasi intrinsik memiliki nilai $>0,50$. Dengan demikian dapat dinyatakan bahwa indikator variabel pada penelitian layak atau valid.

Validitas Diskriminan (Discriminant Validity)

Pengujian ini akan dilihat nilainya menggunakan cross loading dan Fornell Larcker Criterion. Suatu indikator dinyatakan memenuhi syarat discriminant validity apabila cross loading sindikator pada variabelnya adalah terbesar dibandingkan pada variabel lainnya dan indikator indikator menenuhi syarat discriminant validity apabila nilai fornell larcker criterion (nilai akar AVE > dari nilai korelasi).

\begin{tabular}{|c|c|c|c|c|}
\hline & Indikator & $\begin{array}{l}\text { Kepemimpinan } \\
\text { transformasional }\end{array}$ & Kinerja pegawai & $\begin{array}{l}\text { Motivasi } \\
\text { intrinsik }\end{array}$ \\
\hline & Pengaruh ideal (attributes) & 0,706 & 0,450 & 0,489 \\
\hline & Pengaruh ideal (behaviors) & 0,725 & 0,629 & 0,506 \\
\hline & Motivasi Inspirasional & 0,869 & 0,594 & 0,685 \\
\hline & Stimulasi Intelektual & 0,822 & 0,567 & 0,632 \\
\hline & Perilaku individu. & 0,815 & 0,648 & 0,552 \\
\hline & Jumlah pekerjaan & 0,573 & 0,785 & 0,534 \\
\hline & Kualitas pekerjaan & 0,673 & 0,822 & 0,609 \\
\hline & Ketepatan Waktu & 0,622 & 0,841 & 0,560 \\
\hline & Kehadiran & 0,510 & 0,778 & 0,556 \\
\hline & Kemampuan kerja sama & 0,487 & 0,700 & 0,622 \\
\hline & Keberhasilan & 0,529 & 0,552 & 0,758 \\
\hline & Pengakuan & 0,342 & 0,524 & 0,716 \\
\hline Tabel 4 & Pekerjaan itu sendiri & 0,527 & 0,598 & 0,728 \\
\hline \multirow[t]{3}{*}{ Cross loading } & Tanggung jawab & 0,645 & 0,562 & 0,764 \\
\hline & Pengembangan & 0,589 & 0.486 & 0,756 \\
\hline & Variabel & $\begin{array}{c}\text { Kepemimpinan } \\
\text { transformasional }\end{array}$ & $\begin{array}{r}\text { Kinerja } \\
\text { pegawai }\end{array}$ & $\begin{array}{l}\text { Motivasi } \\
\text { intrinsik }\end{array}$ \\
\hline Tabel 5 & Kepemimpinan Transformasional & 0,790 & & \\
\hline Fornell Larcker & Kinerja pegawai & 0,736 & 0,787 & \\
\hline Criterion & Motivasi intrinsik & 0,730 & 0,730 & 0,745 \\
\hline
\end{tabular}


Berdasarkan hasil yang diperoleh tersebut, dapat dinyatakan bahwa variabel dan indikator yang digunakan dalam penelitian ini telah memiliki validitas diskriminan yang baik, berdasarkan syarat yang telah ditentukan.

\section{Reliabilitas}

Berdasarkan data pada tabel diatas 3 dapat diketahui nilai composite reliability dari masingmasing variabel penelitian $>0,70$. Hasil ini menunjukan bahwa masing-masing variabel telah memenuhi syarat composite reliability sehingga dapat dinyatakan bahwa variabel penelitian memiliki tingkat reliabilitas yang baik dan dapat diterima.

Kemudian berdasarkan data pada tabel 3 diatas, dapat diketahui nilai cronbach's alpha dari masing-masing variabel penelitian $>0,60$. Hasil ini menunjukan bahwa masing-masing variabel telah memenuhi syarat cronbach's alpha sehingga dapat dinyatakan bahwa variabel penelitian memiliki tingkat reliabilitas yang baik dan dapat diterima.

\section{Hasil Penelitian Inner Model}

Pada penelitian ini akan dijelaskan hubungan antara variabel berdasarkan nilai yang didapat dari path coefficient . Sehingga evaluasi hasil Inner Model atau Model Struktural dapat dilihat pada tabel 6 sebagai berikut :

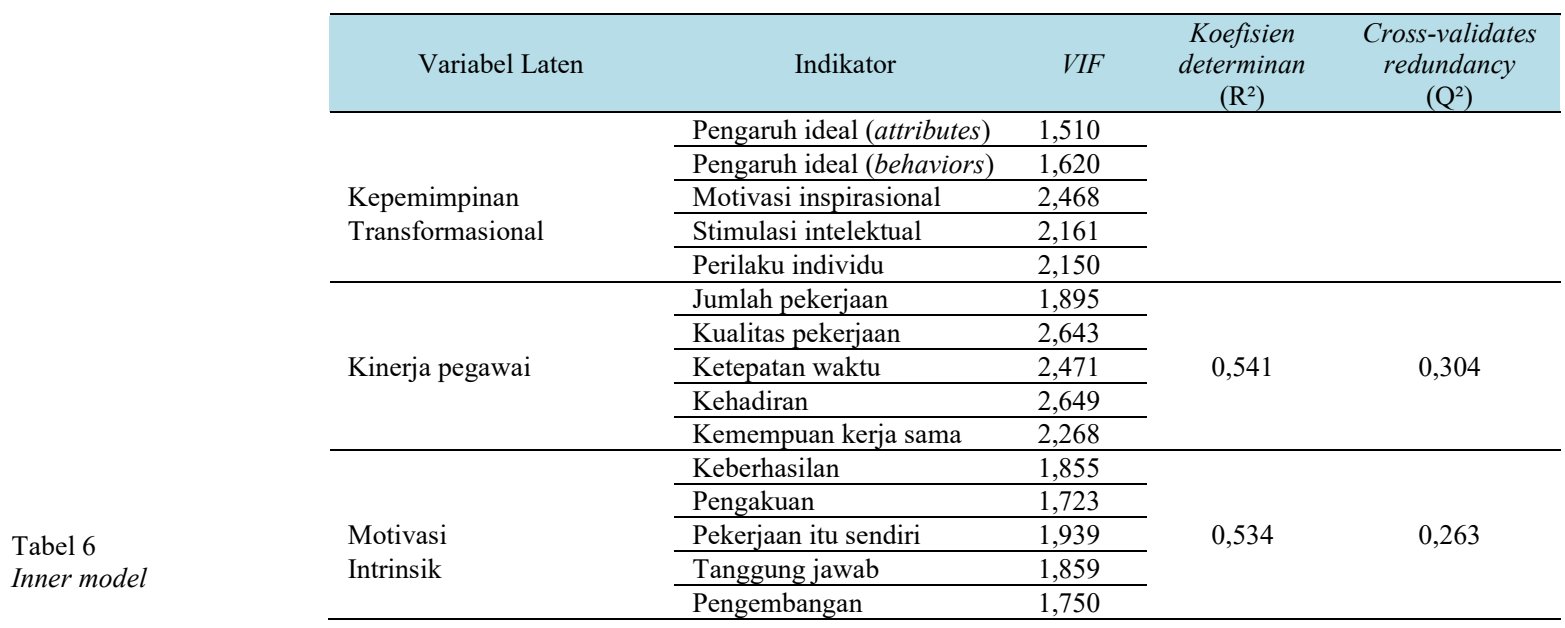

Berdasarkan pada tabel 6 diatas menjelaskan hasil penelitian yaitu evaluasi model berdasarkan VIF telah memenuhi syarat yaitu dibawah dari angka 5 artinya tidak terjadi kolinearitas pada masing-masing indikator variabel.

Untuk melihat seberapa kuat variabel endogen dipengaruhi oleh variabel lainnya dapat dilihat dari nilai R-square. Berdasarkan hasil data pada tabel 6 diatas, dapat diketahui Rsquare untuk kinerja pegawai (Y1) sebesar 0,541 yang berarti variabel kepemimpinan transformasional $(\mathrm{X})$ mempengaruhi variabel kinerja (Y1) sebesar 0,541 atau 54,1\%, sedangkan 45,9\% dipengaruhi variabel lain diluar penelitian ini. Sedangkan untuk variabel motivasi intrinsik (Y2) nilai R-square sebesar 0,534 yang artinya variabel kepemimpinan transformasional $(\mathrm{X})$ mempengaruhi variabel motivasi intrinsik (Y2) sebesar 0,534 atau $53,4 \%$ sedangkan $46,6 \%$ dipengaruhi variabel lain diluar penelitian ini.

Selanjutnya pengujian Q-square test dengan menggunakan prediction relevance, Qsquare digunakan untuk mengukur seberapa baik nilai observasi. Perhitungan Q-square menghasilkan nilai dari konstruk variabel kinerja sebesar 0,304 atau lebih besar dari 0 dan motivasi intrinsik dengan nilai 0,263 atau lebih besar dari 0 . Hasil tersebut menjelaskan bahwa kedua konstruk yaitu kinerja dan motivasi intrinsik tersebut akurat. 


\section{Uji Hipotesis}

Ukuran signifikan keterdukungan hipotesis dapat digunakan perbandingan nilai T-tabel dan T-statistic, jika T-statistic lebih tinggi dibandingkan nilai $\mathrm{T}$-tabel berarti hipotesis terdukung atau diterima (Jugiyanto dan Abdillah 2009). T-tabel yang digunakan dalam penelitian ini dengan tingkat signifikan 5\% sebesar 0,273 Analisis PLS (Partial Least Square) yang digunakan dalam penelitian ini menggunakan SmartPLS versi 3.2.8. Untuk menilai hubungan model prediksi dalam pengguji model struktural, dapat dilihat dari nilai original sample estimate dan nilai $t$-statistic pada tabel 7 Path Coefficient berikut ini :

\begin{tabular}{|c|c|c|c|c|c|c|c|}
\hline & $\begin{array}{c}\text { Hubungan antar } \\
\text { variabel }\end{array}$ & $\begin{array}{c}\text { Original } \\
\text { Sample } \\
\text { Estimate }\end{array}$ & $\begin{array}{r}\text { Sample } \\
\text { Mean }\end{array}$ & STDEV & $\begin{array}{c}\text { T - } \\
\text { Statistik }\end{array}$ & $\begin{array}{c}P \text { - } \\
\text { Value }\end{array}$ & Keputusan \\
\hline & $\begin{array}{l}\text { Kepemimpinan } \\
\text { Transformasional } \\
\text {-> Kinerja pegawai }\end{array}$ & 0.736 & 0.743 & 0.066 & 11.153 & 0.000 & Diterima \\
\hline $\begin{array}{l}\text { Tabel } 7 \\
\text { Path Coefficient }\end{array}$ & $\begin{array}{l}\text { Kepemimpinan } \\
\text { Transformasional } \\
\text {-> Motivasi Intrinsik }\end{array}$ & 0.730 & 0.744 & 0.068 & 10.768 & 0.000 & Diterima \\
\hline
\end{tabular}

Berdasarkan tabel 7 diatas, maka KT tehadap KP dilihat dari nilai original sample estimate adalah positif yaitu sebesar 0,736 yang menunjukkan arah hubungan antara KT tehadap KP adalah positif dengan nilai t-statistic sebesar 20,056. Sehingga didapatkan kesimpulan bahwa t-statistic lebih besar dari pada t-tabel $(11,153>0,273)$. Sedangkan taraf signifikansinya memiliki nilai 0,000 $(\mathrm{P}<0,005)$. Dapat disimpulkan bahwa KT berpengaruh positif terhadap KP dan hipotesis 1 diterima.

KT tehadap MI dilihat dari dari nilai original sample estimate adalah positif yaitu sebesar 0,730 yang menunjukkan arah hubungan antara KT tehadap MI adalah positif dan dilihat dari nilai t-statistic sebesar 10,768. Sehingga didapatkan kesimpulan bahwa t-statistic lebih besar dari pada t-tabel $(10,768>0,273)$. Sedangkan taraf signifikansinya memiliki nilai $0,000(\mathrm{P}<$ 0,005). Dapat disimpulkan bahwa KT memiliki pengaruh positif MI dan hipotesis 2 diterma.

\section{Pembahasan}

Semakin meningkat gaya kepemimpinan transformasional yang dirasakan oleh pegawai maka semakin tinggi kinerja yang diberikan para pegawai. Kinerja yang diukur dengan jumlah pekerjaan, kualitas pekerjaan, ketepatan waktu, kehadiran dan kemampuan kerjasama. Berdasarkan penilaian pegawai kinerja digambarkan dengan penyelesaian pekerjaan tepat waktu atau ketepatan waktu yang dimana tujuan pemimpin adalah memberdayakan pegawai untuk bekerja lebih optimal. Ketepatan waktu dalam melakukan pekerjaan membuktikan bahwa kepemimpinan transformasional telah dikelola dengan baik sehingga dapat meningkatkan kinerja. Hal ini sejalan dengan penelitian (Augi et al., 2020; Lai et al., 2020; Yammarino et al., 1993), bahkan tidak hanya kinerja pegawai saja juga mampu meningkatkan kreativitas pegawai dalam bekerja (Jyoti \& Dev, 2015; Sambung, 2020; Shafi et al., 2020). Indikator dari kepemimpinan transformasional seperti pengaruh ideal (attributes), pengaruh ideal (behaviors), motivasi inspirasional, stimulasi intelektual, dan perilaku individu merupakan indikator yang mampu menjelaskan atau menggambarkan gaya kepemimpinan transformasional. Dapat disimpulkan bahwa motivasi inspirasional merupakan indikator yang dominan dalam menggambarkan kepemimpinan transformasional dalam penelitian ini.

Kepemimpinan transformasional yang digambarkan dengan motivasi inspirasional yang ditunjukkan pemimpin dalam sebuah organisasi maka akan meningkat pula kinerja pegawainya. Kepemimpinan transformasional diukur dengan Pengaruh ideal (attributes), 
pengaruh ideal (behaviors), motivasi inspirasional, stimulasi intelektuak, dan perilaku individu. Berdasarkan penilaian para pegawai kepemimpinan transformasional digambarkan dengan pemimpin mendorong saya untuk selalu inovatif dalam menyelesaikan pekerjaan yang dapat menumbuhkan semangat kerja pegawai. Semakin bagus kepemimpinan transformasional yang diterapkan pemimpin maka akan memberikan keyakinan bahwa motivasi akan meningkat. Hal ini sejalan dengan penelitian (Masi \& Cooke, 2000; Nugroho et al., 2020). Orang yang menampilkan kepemimpinan transformasional sering kali memiliki kumpulan nilai serta prinsip internal yang kuat. Mereka efektif dalam memotivasi pengikut untuk bertindak dalam cara yang mendukung kepentingan yang lebih besar, dari pada kepentingan mereka sendiri (Northouse 2016).

Hasil penelitian ini berimplikasi nyata dalam pengembangan keilmuan terutaman pada teori kepemimpinan yang banyak diminati untuk diteliti. Bahkan hasil penelitian ini juga berimplikasi pada pengembangan gaya kepemimpinan yang perlu ditunjukkan pada organisasi atau kantor pemerintahan.

\section{SIMPULAN}

Kepemimpinan transformasional lebih dominan dalam mempengaruhi kinerja pekerjaan secara langsung dibandingkan dalam meningkatkan motivasi intrinsik pegawai. Namun hasil peneilitian ini memberikan kontribusi nyata dalam menjelaskan dampak langsung dari gaya kepemimpinan tersebut. Penelitian ini telah diusahakan dan dilaksanakan sesuai dengan prosedur ilmiah, namun demikian masih memiliki keterbatasan, seperti sampel yang digunakan terbatas pada satu organisasi pemerintahan, sehingga belum memberikan hasil yang dapat digeneralisasikan pada seluruh organisasi pemerintahan. Bagi peneliti selanjutnya hasil penelitian ini diharapkan dapat memperluas populasi yang digunakan, sehingga mampu memberikan kesimpulan menyeluruh untuk semua kantor pemerintahan, khususnya di Kota Palangka Raya.

\section{REFERENSI}

Augi, G. G., Sambung, R., \& Panjaitan, O. W. O. (2020). Pengaruh Gaya Kepemimpinan Demokratik Terhadap Kinerja Karyawan Dengan Menggunakan Motivasi Sebagai Variabel Moderator. Jurnal Manajemen Sains Dan Organisasi, 1(1), 1-15. https://doi.org/10.52300/jmso.v1i1.2366

Babin, B. J., \& Boles, J. S. (1998). Employee Behavior in a Service Environment: A Model and Test of Potential Differences between Men and Women. Journal of Marketing, 62(2), 77-91. https://doi.org/10.1177/002224299806200206

Bass, B. M., \& Avolio, B. J. (1994). Transformational leadership, organizational culture. International Journal of Public Administration, 17(3-4), 541-554. https://doi.org/10.1080/01900699408524907

Carter, M. Z., Mossholder, K. W., Feild, H. S., \& Armenakis, A. a. (2014). Transformational Leadership, Interactional Justice, and Organizational Citizenship Behavior : The Effects of Racial and Gender Dissimilarity Between Supervisors and Subordinates. Group \& Organization Management - B, 39. https://doi.org/10.1177/1059601114551605

Ghozali, I., \& Latan, H. (2015). Partial Least Square Konsep, Teknik dan Aplikasi menggunakan Program SmartPLS 3.0 Ed Ke-2. Badan Penerbit Universitas Dipenogoro, Semarang

Gumusluoglu, L., \& Ilsev, A. (2009). Transformational leadership, creativity, and organizational innovation. Journal of Business Research, 62(4), 461-473. https://doi.org/10.1016/j.jbusres.2007.07.032 
Jyoti, J., \& Dev, M. (2015). The impact of transformational leadership on employee creativity: The role of learning orientation. Journal of Asia Business Studies. https://doi.org/10.1108/JABS-03-2014-0022

Lai, F. Y., Tang, H. C., Lu, S. C., Lee, Y. C., \& Lin, C. C. (2020). Transformational Leadership and Job Performance: The Mediating Role of Work Engagement. SAGE Open, 10(1). https://doi.org/10.1177/2158244019899085

Masi, R. J., \& Cooke, R. A. (2000). Effects of Transformational Leadership on Subordinate Motivation, Empowering Norms, and Organizational Productivity. The International Journal of Organizational Analysis, 8(1), 16-47. https://doi.org/10.1108/eb028909

Nugroho, Y. A., Asbari, M., Purwanto, A., Basuki, S., Sudiyono, R. N., Fikri, M. A. A., Hulu, P., Mustofa, Chidir, G., Suroso, \& Xavir, Y. (2020). Transformational Leadership and Employees' Performance: the Mediating Role of Motivation and Work Environment. EduPsyCouns: Journal of Education, Psychology and Counseling, 2(1), 438-460. https://ummaspul.e-journal.id/Edupsycouns/article/view/507

Sambung, R. (2020). Pelatihan dan Kepemimpinan Visioner dalam meningkatkan Kreativitas Pegawai di Kalimantan Tengah. Matrik: Jurnal Manajemen, Strategi Bisnis Dan Kewirausahaan, 169-181. https://doi.org/https://doi.org/10.24843/MATRIK:JMBK.2020.v14.i02.p04

Seltzer, J., \& Bass, B. M. (1990). Transformational Leadership: Beyond Initiation and Consideration. Journal of Management, 16(4), 693-703. https://doi.org/10.1177/014920639001600403

Shafi, M., Zoya, Lei, Z., Song, X., \& Sarker, M. N. I. (2020). The effects of transformational leadership on employee creativity: Moderating role of intrinsic motivation. Asia Pacific Management Review, 25(3), 166-176. https://doi.org/10.1016/j.apmrv.2019.12.002

Sarstedt, M., Ringle, C. M., \& Hair, J. F. (2017). Partial least squares structural equation modeling. Handbook of Market Research, 1-40.

Suifan, T. S., Abdallah, A. B., \& Al Janini, M. (2018). The impact of transformational leadership on employees' creativity: The mediating role of perceived organizational support. Management Research Review, 41(1), 113-132. https://doi.org/10.1108/MRR02-2017-0032

Wong, K. K. (2013). PLS-SEM Techniques Using SmartPLS. Marketing Bulletin. https://doi.org/10.1108/EBR-10-2013-0128

Yammarino, F. J., Spangler, W. D., \& Bass, B. M. (1993). Transformational leadership and performance: A longitudinal investigation. The Leadership Quarterly, 4(1), 81-102. https://doi.org/10.1016/1048-9843(93)90005-E

Zhang, H., Liu, Z., \& Wang, Y. (2020). How transformational leadership positively impacts organizational citizenship behavior in successful Chinese social work service organizations. Nonprofit Management and Leadership, 30(3), 467-485. https://doi.org/10.1002/nml.21391

corresponding author

e-mail: desinatalia.febupr@gmail.com 